International Journal of Scholarly Papers for Media and Communications

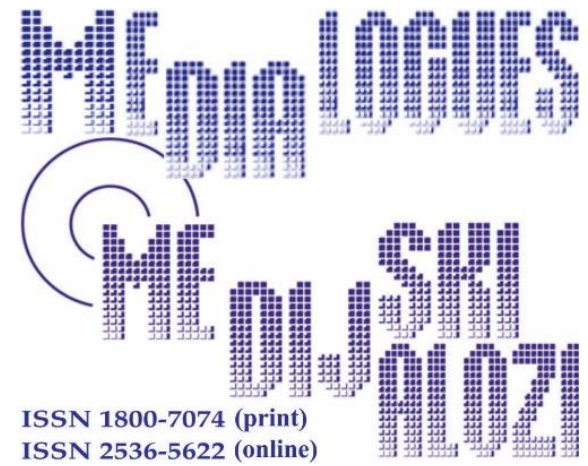

Spaic, A., Nolasco, C. (2012), ,Media Coverage in Minor Proceeding: in the Light of Krone Case of ECHR", Media Dialogues / Medijski dijalozi,

Vol. 14, No. 4, pp. 47-56.

\title{
Media Coverage in Minor Proceeding: in the Light of Krone Case of ECHR
}

\author{
Assistant Professor ANETA SPAIC, \\ University of Montenegro, School of Law, \\ Podgorica, Montenegro \\ Assistant Professor CLAIRE NOLASCO, \\ Texas A\&M University, \\ San Antonio, USA
}

\begin{tabular}{|c|c|}
\hline $\boldsymbol{A} \boldsymbol{R} \boldsymbol{T} \boldsymbol{I} \boldsymbol{C L} \boldsymbol{E}$ & Received: April 16, 2021 / Revised from: May 14, 2021 \\
$\boldsymbol{I} \boldsymbol{N} \boldsymbol{F} \boldsymbol{O}$ & Accepted: June 14, 2021 / Available online: October 15, 2021 \\
\hline DOI & doi.org/10.14254/1800-7074/14-4/3 \\
\hline
\end{tabular}

\section{ABSTRACT}

Freedom of expression is defined as one of the main pillars of any democratic society. Transitional countries as well as true democracies are faced with the problem of complying with international standards governing the exercise of this right, 
especially when it collides with the other rights of equal significance, such as the right to privacy. This issue is further compo- unded when it involves a vulnerable group of the population - minors, when they are processed within the criminal justice system. Juvenile delinquency is considered a serious legal and social problem facing not only children, teachers, or parents, but also the professional media. Members of the press and media are expected to carefully and accurately report on juvenile delinquency, bearing in mind their role and importance in the creation and presentation of views on this important issue not only to lay public, but sometimes the experts, and even the judges. To enable adequate treatment of this sensitive issue involving the conflict of two important rights - the freedom of expressi- on and the right to privacy - and after careful analysis of the European legal framework, this paper aims to present the reasoning and logic behind the re-cent judgment of the European Court of Human Rights dealing with this question (Krone Verlag GmbH \& Co KG and Krone Multimedia GmbH \& Co KG v. Austria case, No. 33497/07 dated on 17.01.2012).

KEYWORDS: Freedom of expression, right to privacy, media coverage, juvenile justice

\section{INTRODUCTION}

The rights of media and freedom of the press are paramount concerns, not only in the transitioning countries, but also in democratic countries (Vodinelic, 2010, p. 71). The exact scope, boundaries, and limitations on these rights are not delineated due to the undeveloped legal climate and inexperience of civil courts and society with implementing such rights. Even more pressing are situations where the rights of media and the press conflict with internationally established legal rights of individuals, as in the case of minors. In juvenile proceedings, therefore, there is a clash between the rights of the juvenile to confidentiality and protection of his best interests and the right of the media to access of information. When the rights of two interest groups such as the press and the juvenile offender come into conflict, the courts and the legal community are tasked with providing a framework for resolution. However, in countries that have only recently recognized the right of free press and free speech, there is the problem that these rights will be practiced in excess or even abused to the detriment of other conflicting rights such as the individual right to privacy.

The analysis of the most recent decision of the European Court of Human Rights, Krone case in the abovementioned scenario, requires analysis of the legal framework for media access to juvenile proceedings, current international standards, laws, and recommendations. 


\section{EUROPEAN LEGAL FRAMEWORK}

\subsection{Freedom of expression}

Freedom of expression constitutes one of the essential foundations of a democratic society and one of the basic conditions for its progress, as precisely stipulated under the most authoritative legal text in that area, Article 10 of the European Convention of Human Rights. However, of equal significance is the right of privacy, stated under Article 8 of the Convention, the implementation of which often assumes legal collision with freedom of press. This potential collision has been debated from the perspective of the freedom of the press, including media coverage, and the juvenile's right to privacy. The European Court of Human Rights, analyzing all national available legal instruments, decided in the Krone case in favor of the juvenile's right to privacy, holding that the public policy reason was not present for the eventual disclosure of the identity of the juvenile.

The European Court of Human Rights analyzed media access to juvenile justice within the context of compulsory legal texts such as the European Convention of Human Rights and Fundamental Freedom, Charter of the fundamental rights of European Union and several relevant recommendations such as No. Rec (85)11 and No. $\operatorname{Rec}(87) 20.1^{1}$

The European Convention (Article 10) stipulates that "everyone has the right to freedom of expression, this right shall include freedom to hold opinions and to receive and impart information and ideas without interference by public authority and regardless of frontiers. This Article shall not prevent states from requiring the licensing of broadcasting, television or cinema enterprises."

Every right, including freedom of expression, may be limited but in the manner and under circumstances prescribed by law. Article 10 paragraph 2 of the European Convention explicitly provides that freedom of expression "since it carries with it duties and responsibilities, may be subject to such formalities, conditions, res- trictions or penalties as prescribed by law and are necessary in a democratic society, in the interests of national security, territorial integrity or public safety, for the prevention of disorder or crime, for the protection of health or morals, for the protection of the reputation or rights of others, for preventing the disclosure of information received in confidence, or for maintaining the authority and impartiality of the judiciary."

\subsection{Right of Privacy of a Child}

One of the cornerstones of a democratic society is the right to information and the public's right to receive information of public interest. This right should be under-

\footnotetext{
${ }^{1}$ Convention for the Protection of Human Rights and Fundamental Freedom, as amended by Protocol No. 11 and No. 14.
} 
stood as the ability to do anything that does not harm others, and thus it means that the limits of the right to information are conditioned by other's rights. None of the guaranteed rights can ever be absolutely enjoyed without limitations. On the contrary, as general postulate in law, the right can be exercised up to the infringement of other internationally recognized rights. However, one must not unreasonably restrict freedom of the expression, either through misuse by the public or by private authority.

The media often violate people's privacy by referring to unilateral interpretation of the right to freedom of expression as guaranteed by Article 10 of the European Convention on Human Rights. However, it is necessary to find a way to balance these two fundamental rights, both guaranteed by the European Convention on Human Rights: the right to respect for one's private life and the right to freedom of expression. Therefore, a proceeding that involves a child such as juvenile proceedings, has to absolutely adhere to the principle of the confidentiality. This has been determined as the vital interest in ensuring fair trial without intimidation and victimization of the child.

On one hand, Article 8 of the European Convention on Human Rights calls for respect for private and family life, providing that: "Everyone has the right to respect for his private and family life, his home and his correspondence. There shall be no interference by a public authority with the exercise of this right except such as is in accordance with the law and is necessary in a democratic society in the interests of national security, public safety or the economic well-being of the country, for the prevention of disorder or crime, for the protection of health or morals, or for the protection of the rights and freedoms of others."

Furthermore, children's access to justice at national and international level became one of the pillars of the Council of Europe Strategy on the Rights of the Child 2009-201 $1^{3}$ and Guidelines of the Committee of Ministers of the Council of Europe on child-friendly justice and their explanatory memorandum ${ }^{4}$. The Beijing Rules, as

\footnotetext{
${ }^{2}$ The entire text of the Convention see at: http://www.echr.coe.int/nr/rdonlyres/d5cc24a7-dc13-4318b457- 5c9014916d7a/0/englishanglais.pdf

${ }^{3}$ Guidelines of the Committee of Ministers of the Council of Europe on child-friendly justice and their explanatory memorandum (Adopted by the Committee of Ministers on 17 November 2010 at the 1098th meeting of the Ministers' Deputies) Guidelines and Explanatory memorandum - version edited 31 May 2011. http://www.coe.int///dghl/standardsetting/ childjustice/Guidelines\%20on\%20childfriendly\%20justice\%20and\%20their\%20explanatory\% 20memorandum\%20_4_pdf

${ }^{4}$ Guidelines, p. 6:

"2. Protection of private and family life

6. The privacy and personal data of children who are or have been involved in judicial or non-judicial proceedings and other interventions should be protected in accordance with national law. This generally implies that no information or personal data may be made available or published, particularly in the media, which could reveal or indirectly enable the disclosure of the child's identity, including image, detailed descriptions of the child or the child's family, names or addresses, audio and video records, etc.

7. Member states should prevent violations of the privacy rights as mentioned under guideline
} 
not binding rules in international law, were adopted by the United Nations General Assembly in 1985. Article 8, paragraph 1 on the Protection of Privacy of these Rules stipulates that: " $(t)$ he juvenile's privacy shall be respected at all stages in order to avoid harm being caused to her or him by undue publicity or by the process of labeling. Furthermore, in the paragraph 2 of the same article states that, "(i)n principle, no information that may lead to the identification of a juvenile offen-der shall be published". Furthermore, with respect to the disposition of the competent authorities in article 17 of the same text, it is stipulated that "the reaction taken shall always be in proportion not only to the circumstances and gravity of the offense but also to the circumstances and the needs of the child as well as to the needs of the society... The well-being of the juvenile shall be the guiding factor in the consideration of her or his case."

The United Nations Convention On The Rights Of The Child $1989^{5}$, the binding force under international law, under Article 3(i) states that "In all actions concerning children, whether undertaken by public or private social welfare institutions, courts of law, administrative authorities or legislative bodies, the best interests of the child shall be a primary consideration." Article 40 of the same Convention provides that "State Parties recognize the right of every child alle-ged as, accused of, or recognized as having infringed the penal law to be treated in a manner consistent with the promotion of the child's sense of dignity and worth, which reinforces the child's respect for the human rights and fundamental freedoms of others and which takes into account the child's age and the desirability of promoting the reintegration and the child's assuming a constructive role in society." The next line of the same paragraph provides that, "the States Parties shall, in particular,

6. Above by the media through legislative measures or monitoring self-regulation by the media.

8. Member states should stipulate limited access to all records or documents containing personal and sensitive data of children, in particular in proceedings involving them. If the transfer of personal and sensitive data is necessary, while taking into account the best interests of the child, member states should regulate this transfer in line with relevant data protection legislation.

9. Whenever children are being heard or giving evidence in judicial or non-judicial proceedings or other interventions, where appropriate, this should preferably take place in camera. As a rule, only those directly involved should be present, provided that they do not obstruct children in giving evidence.

10. Professionals working with and for children should abide by the strict rules of confidentiality, except where there is a risk of harm to the child. 3. Safety (special preventive measures)

11. In all judicial and non-judicial proceedings or other interventions, children should be protected from harm, including intimidation, reprisals and secondary victimization.

12. Professionals working with and for children should, where necessary, be subject to regular vetting, according to national law and without prejudice to the independence of the judiciary, to ensure their suita- bility to work with children.

13. Special precautionary measures should apply to children when the alleged perpetrator is a parent, a member of the family or a primary caregiver."

5 The United Nations Convention On The Rights Of The Child 1989 was adopted by the General Assembly of the United Nations on 20 November 1989 
ensure that '(e)very child alleged as or accused of having infringed the penal law has ... his or her priva-cy fully respected at all stages of the proceedings."

Furthermore, it stipulates that "States Parties shall seek to promote the establishment of laws, procedures, authorities and institutions, specifically applicable to children alleged as, accused of, or recognized as having infringed the penal law, and, in particular: (b) whenever appropriate and desirable, measures for the dealing with such children without resorting to judicial proceedings, providing that human rights are fully respected...."

In a similar manner to article 6 of the European Convention, Article 14(4) International Covenant On Civil And Political Rights 1966 (ICCPR) stipulates that: "In the case of juvenile persons, the procedure shall be such as will take account of their age, and the desira- bility of promoting their rehabilitation." Convention on the Protection of Children against Sexual Exploitation and Sexual Abuse, Article 31 reads as follows: "(1) Each party shall take the necessary legislative or other measures to protect the rights and interests of victims, inclu-ding their special needs as witnesses, at all stages of investigations and criminal proceedings, in particular by:... (e) protecting their privacy, their identity and their image and by taking measures in accordance with international law to prevent the public dissemination of any information that could lead to their identification".

In the Explanatory Report to the Con- vention on the Protection of Children against Sexual Exploitation and Sexual Abuse, paragraph 222 gives the following comment on Article 31 of that Convention: "The article goes on to list a number of procedural rules designed to implement the general principles set out in Article 31: The possibility for victims of being heard, of supplying evidence, of having their privacy, particularly their identity and image protected, and of being protected against any risk of retaliation and repeat victimization. The negotiators wished to stress that the protection of the victim's identity, image and privacy extends to the risk of 'public' disclosure, and that these requirements should not prevent this information being revealed in the context of the actual proceedings, in order to respect the principles that both parties must be heard and the inherent rights of the defence during a criminal prosecution."

It also seems relevant to mention one of the most relevant legal texts, without the compulsory effects, Recommendation Rec (85)117 dealing with "the position of the victim in the framework of criminal law and procedure." In section F (Protection of privacy) point 15 reads as follows: "Information and public relations policy in connection with the investigation and trial of offences should give due consideration to the need to protect the victim from any publicity which will unduly affect his priva-

\footnotetext{
${ }^{6}$ Council of Europe Convention on the Protection of Children against Sexual Exploitation and Sexual Abuse (General measures of protection) of 25 October 2007, CETS No. 201.

${ }^{7}$ This Recommendation No. Rec (85) 11 has been adopted by Committee of Ministers of the Council of Europe on 28 June 1985.
} 
te life and dignity. If the type of offence or the particular status or personal situation and safety of the victim make such a special protection necessary, either the trial before the judgment should be held in camera or disclosure or publication of personal information should be restricted to whatever extent is appropriate."

Recommendations No. Rec (87) $20^{8}$ stipulates "that social reactions to juvenile delinquency should take account of the personality and specific needs of minors, and that the latter need specialized interventions and, where appropriate, specialized treatment, based in particular on the principles embodied in the United Nations Declaration of the Rights of the Child. Furthermore, having regard to the United Nations Standard Minimum Rules for the Administration of Juvenile Justice ("the Beijing Rules"), it recommends the governments of member states to review, if necessary, their legislation and practice with a view:... 4) to ensuring that minors are tried more rapidly, avoiding undue delay, so as to ensure effective educational action; ... 8) to reinforcing the legal position of minors throughout the proceedings by recognizing inter alia: ... the right of juveniles to respect for their private lives..."

Recommendation $\operatorname{Rec}(2001) 16$ on the protection of children against sexual exploitation ${ }^{9}$, under Article III point 32 stipulates that judicial, mediation or administrative proceedings should enjoy the confidentiality of records and respect for the privacy of children who have been victims of sexual exploitation.

In addition to it, the appendix to the Recommendation Rec (2003) $13^{10}$ on the provision of information, through the media in relation to criminal proceedings, contains the following principle 8 on the Protection of privacy in the context of ongoing criminal proceedings: The provision of information about suspects, accused or convicted persons or other parties to criminal proceedings should respect their right to protection of privacy in accordance with.

Article 8 of the Convention. „Particular protection should be given to parties who are minors or other vulnerable persons, as well as to victims, to witnesses and to the families of suspects, accused and convicted. In all cases, particular consideration should be given to theb harmful effect which the disclosure of information enabling their identification may have on the persons referred to in this Principle. An even stronger protection is recommended to parties who are minors, to victims of criminal offences, to witnesses and to the families of suspects, the accused and convicted persons..."

\footnotetext{
${ }^{8}$ Recommendations No. Rec (87) 20 has been adopted on September 17, 1987 the Committee of Ministers of the Council of Europe.

${ }^{9}$ Recommendation Rec(2001)16 has been adopted on 31 October 2001 the Committee of Ministers of the Council of Europe.

${ }^{10}$ Recommendation Rec(2003)13 has been adopted on 10 July 2003 the Committee of Ministers of the Council of Europe.
} 


\section{THE ANALYSIS OF THE COURT FINDINGS}

To provide a legal framework within the European legal community that reconciles the clash between these two rights, the authors provide an analysis of the ratio legis of the decision which in January had become the part of the EUHR case law, Krone Verlag GmbH \& Co KG and Krone Multimedia GmbH \& Co KG v. Austria case (hereinafter referred to as Krone case).

In the Krone Verlag GmbH \& Co KG and Krone Multimedia GmbH \& Co KG v. Austria case (Application No.33497/07, dated on 17 January 2012, Strasbourg), A and B were suspected of the repeated and serious illtreatment and sexual abuse of $\mathrm{C}$, causing the latter severe injuries. The biological mother of C, D cooperated with the newspaper by providing it with the picture of $C$ in 2003, when she was three and was later sporadically being given the custody to $\mathrm{C}$.

The applicants - the daily newspaper Kronen Zeitung and the owner of the online newspaper www.krone.at complained before the European Court of Human Rights on the final decision of the national court of Austria. The Regional Criminal Court in Austria (Landesgericht für Strafsachen), on the ground that the newspaper Kronen Zeitung and www.krone.at in the articles appeared on 16, and 22 February 2005 had caused suffering of $\mathrm{C}$ by violating her private life and publishing the photos of her, revealing C's first name, the full names and pictures of biological father A and step mother B, granted C compensation (4,000 EUR in compensation to C for each of the articles) finding that "the identity of the victim of a criminal offence could only be revealed if there was a predominant public interest in that specific item of information". It also found that $\mathrm{C}$ was entitled to compensation from the second applicant company as the articles published on its website on 16 and 22 February 2005. The Appeal Court dismissed the appeal.

The applicants complained before the EHCJ on the ground that interference had been "necessary in a democratic society" in the light of the Article 10 of the Convention.

In fact, the applicant called upon the violation of the Article 10 (2) of the Convention stating that "dissemination of the information is the part of democratic process particularly when there is the overriding public interest in reporting in every detail on the case in issue, and when reporting in view of the very nature of the criminal offence - violence and sexual abuse within the family". They argued that press shall report in an identifying manner on crimes of sexual abuse of minors within the family revealing the identity of the offender, as accurate and detailed reporting also served to protect and help the victims of such crimes. They stated that reporting with revealing the identity of the offenders was in accordance with the Article 10 of the Convention. The applicant companies further argued that in any event they had been allowed to report on the case in the manner they did in the articles at issue as they had been authorized to do so by $\mathrm{D}$, the biological mother of 
$\mathrm{C}$, in 2003. That authorization logically extended to the publication of the articles on the trial against $\mathrm{A}$ and $\mathrm{B}$.

Under Article 10 of the European Convention and Article 31 of the Council of Europe Convention on the Protection of Children against Sexual Exploitation and Sexual Abuse, which obliges the Contracting States "to take the necessary legislative or other measures to protect the rights and interests of victims, by protecting their identity and by taking measures in accordance with international law to prevent the public dissemination of any information that could lead to their identification". The same concept of protecting the identity of victims of crime has also been recognized in various recommendations adopted by the Committee of Ministers of the Council of Europe (see Recommendations Rec(85)11, Rec(2001)16 and Rec(2003)13.

The Court, invoking prior case law, applied the test of necessity that required examination of whether the interference of media was a result of "pressing social need" and determining to what degree the media should be allowed to fulfill its basic function of being "public watchdog" quoting the Sunday Times v. the United Kingdom (no. 1), 26 April 1979. The Court proceeded to explain that the question before them required the balancing of two competing interests: disclosure of the identity of a victim of a criminal offence as against the media's freedom of expression under Article 10 of the Convention, including the media's right to inform the public on matters of public concern regarding ongoing criminal proceedings. The Court held that the applicant companies, by reporting in the described manner, breached C's right to re- main anonymous intruded into the strictly private life of $\mathrm{C}$, a minor. They determined that there was no prevailing public interest that necessitated the media's disclosure of her identity. The Court also found that the applicant companies could have informed the public in a sufficiently detailed manner without revealing the identity of the accused and thereby that also of the victim, as this particular information had not been essential for understanding the case of $\mathrm{C}$ or served any other specific purpose such as warning and protecting the public. The Court concluded that at the time of the publication at issue no valid consent to the applicant companies' publications had existed as in $2005 \mathrm{D}$ had explicitly revoked her consent given in 2003.

Therefore, the ECHR that there has accordingly been no violation of Article 10 of the Convention. On contrary, the Court granted the requests and ordered both applicant companies to pay compensation.

\section{CONCLUSION}

From the perspective of clash that occurred within the context of these two guaranteed crucial freedoms, accordingly there are at least two crucial legal issues that are to be explained through the corners of the international legislative mandatory and not obligatory texts: 1) freedom of expression as the pillar of any democratic so- 
ciety and the 2) right to privacy, defined under legal instruments as the limiting factor on the scope and definition of the freedom of expression (Smet, 2010, p. 190). When seen and analyzed through the lenses of the most susceptible, social vulnerable group - minors - the conflict between these two rights must be more strictly scrutinized. National laws, usually, make it unclear whether the media has unregulated or restricted access to these proceedings. The legal issues surrounding media coverage of, and access to, juvenile proceedings involve whether the media would be willing to accept certain conditions on their ability to publish information in particular juvenile cases in exchange for access to these proceedings ${ }^{11}$.

In the most recent Krone case brought before the European Court of Human Rights, the Court attempted to establish a future pattern for media access to juvenile proceedings within a broader legal framework that will result in a more standard and uniform application across European nations. Furthermore, this case increases current knowledge of the legal standards and framework for media coverage of juvenile offenders, as the part of the higher education of journalists, dealing and reporting on the juvenile proceedings, judges who are expected to be familiar with the international standards and the practice of European Court of Human Rights. The analysis in this article aims to increase awareness of the boundaries of media role in treating juveniles, and to improve consistency in media access to juvenile proceedings by taking into consideration the findings of the cases before European Court of Human Right.

\section{BIBLIOGRAPHY}

Convention for the Protection of Human Rights and Fundamental Freedom.

Council of Europe Convention on the Protection of Children against Sexual Exploitation and Sexual Abuse.

Guidelines of the Committee of Ministers of the Council of Europe on child-friendly justice and their explanatory memorandum (Adopted by the Committee of Ministers on 17 November 2010 at the 1098th meeting of the Ministers' Deputies) Guidelines and Explanatory memorandum-version edited 31 May 2011. http:/ /www.coe.int/t/dghl/standardsetting/childjustice/Guideli-

nes $\% 20$ on $\% 20$ childfriendly $\% 20$ justice $\% 20$ and $\% 20$ their\%20explanatory $\% 20$ memorandum\% 20_4.pdf

Nikolic, D.L. (2010), Media Law, Official Gazette, Belgrade (in Serbian).

Smet, S. (2010), "Freedom of Expression and the Right to Reputation: Human Rights in Conflict", American University International Law, Review 26, No. 1. Vodinelic, V.V. (2003), Mass Media Law, Faculty of Business Law, Belgrade (in Serbian).

\footnotetext{
${ }^{11}$ In fact, five cases brought before the ECHR (within this legal issue) has shown that there is the consistent practice, although scant.
} 